\title{
Trade Union and Job Changes in Volatile Times: A Systematic Literature Review \& Future Research Agenda
}

\author{
Azizan H Morshidi, Kee Y. Sabariah Kee Mohd Yussof, Muhammad Idris \\ Bullare @ Bahari
}

To Link this Article: http://dx.doi.org/10.6007/IJARBSS/v11-i2/9189

DOI:10.6007/IJARBSS/v11-i2/9189

Received: 11 December 2020, Revised: 15 January 2021, Accepted: 30 January 2021

Published Online: 21 February 2021

In-Text Citation: (Morshidi et al., 2021)

To Cite this Article: Morshidi, A. H., Yussof, K. Y. S. K. M., \& Bahari, M. I. B. @. (2021). Trade Union and Job Changes in Volatile Times: A Systematic Literature Review \& Future Research Agenda. International Journal of Academic Research in Business and Social Sciences, 11(2), 923-937.

\section{Copyright: (c) 2021 The Author(s)}

Published by Human Resource Management Academic Research Society (www.hrmars.com)

This article is published under the Creative Commons Attribution (CC BY 4.0) license. Anyone may reproduce, distribute, translate and create derivative works of this article (for both commercial and non-commercial purposes), subject to full attribution to the original publication and authors. The full terms of this license may be seen

at: http://creativecommons.org/licences/by/4.0/legalcode

Vol. 11, No. 2, 2021, Pg. 923 - 937

Full Terms \& Conditions of access and use can be found at http://hrmars.com/index.php/pages/detail/publication-ethics 


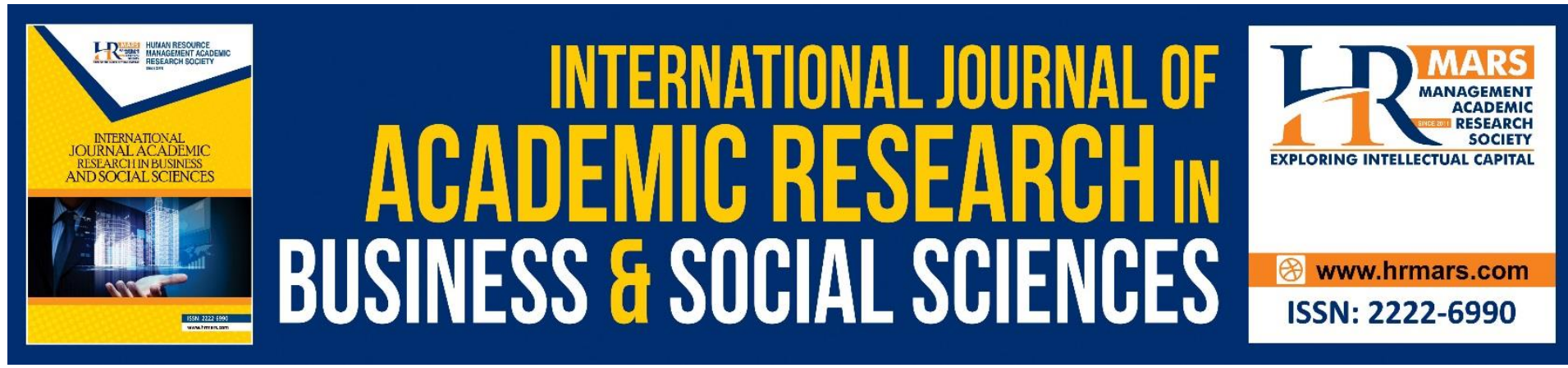

\title{
Trade Union and Job Changes in Volatile Times: A Systematic Literature Review \& Future Research Agenda
}

\author{
Azizan H Morshidi ${ }^{1}$, Kee Y. Sabariah Kee Mohd Yussof ${ }^{2}$, \\ Muhammad Idris Bullare @ Bahari ${ }^{3}$ \\ ${ }^{1,2}$ Faculty of Social Sciences \& Humanities, Universiti Malaysia Sabah, ${ }^{3}$ Faculty of Psychology \\ \& Education, University Malaysia Sabah, Malaysia
}

\begin{abstract}
This article attempts to systematically evaluate and synthesise the existing literature in some factors of job changes, how the trade union response to the problem of job changes during uncertain times and outline future research agenda within the domains. This study could demonstrate how the trade union responses to job rearrangement based on diverse combinations of actions and philosophical bearings in these issues from different perspectives. This study also conducted a systematic literature review by relevant criteria from the resource of studies such as Preferred Reporting Items for Systematic Reviews and Meta-Analyses (PRISMA). It consists of five subsections including search strategy, inclusion and exclusion criteria, eligibility, data abstraction and analysis. Therefore, a systematic search strategy implemented two academic databases, namely Google Scholar and ScienceDirect. The keywords in the titles and abstracts were used in the search process including "job change", "job re-engineering", "job redesign", "workplace restructuring", "workplace reorganisation", "job reshuffle" and "trade union". In this study, the results show that there are dimensions of job changes among employees were relevant because the need for improving organisational and some responses trade union towards job changes among employees. The final inclusion was including the selection of sample involving the respond of trade union about job changes during the uncertainties. The present evidence is limited, and numerous research is required on trade union response on changes in job-related domains during uncertain and volatile times.
\end{abstract}

Keywords: Job Change, Trade Union, Employee, Uncertain Times and Systematic Literature Review

\section{Introduction}

We live in a time of unprecedented uncertainty or volatility. The new age of rapid technological change and growth, modernisation, competitive pressure and the health crisis has placed workers' unions under immense tension to reform Taylor's conventional modes of employment. As the transition to more flexible work organisation models continues, there is a substantial variation in the outcomes of these reform steps. Fundamentally, work changes 
often include a geographical aspect, either intra-regional or inter-regional. Highly skilled people have been shown to make a positive contribution to job changes in regional development by widening the knowledge base of the economy and rising entrepreneurial activity and, ultimately, productivity growth. In the labour market, workers obtain new knowledge of work with a more substantial quality balance between their new skills and practical work requirements than is currently the case. This case happened when a better quality match job was identified between workers and employers to learn about the qualifications of their employees. Job shifts are typically closely connected to employer choices, with job vacancies outside the regional borders of employees. At the beginning of this report, the process of work transition, including shifts in jobs, roles, hours and skills, is one of the critical factors in the functioning of the labour market (Villajos et al., 2019).

This research contains several materials that increase or decrease skill levels as individual roles change among workers. Besides, the study discussed shifts in jobs, including adjustments in employers, roles with the same employer, hours, duties and more. It was suggested that union moderation would have several negative implications for unions, which would impede the growth of union operations in the workplace, and that it would be one of the philosophies of collective interest that would decrease the desire and potential of union members. Union officials are consolidated under every regulation controlled by employers in the decision-making process. This fact also encourages employers to reap the benefits of union flexibility and to restructure employees to the detriment of labour rights and conditions (Villajos et al., 2019).

In contrast, according to Kelly (2012), evidence has been used of the negative impact of non-strike unions and new style agreements in the United Kingdom in the 1980s. Any observational test using Kell's militancy, which is a moderation scale, showed mixed results in the United Kingdom (Bacon and Blyton, 2002). This issue has been linked to a coalition of more decisive trade union actions and greater involvement by management in the resolution of organisational problems and long-term market strategies between employees and employers. The tactic used by the union in collective bargaining seemed at least as necessary as mobilising union members to make profits for employees. This tactic showed that there was again no indication that the members had significantly affected many terms and conditions, and that the mainstream trade unionists were no longer inclined to preserve a unitary system of reference. There have been other studies on change in the workplace that relate labour union reactions to quality job insecurity and aim to explain how top-down changes in working processes, procedures and technology have led to workers' fears of losing valued jobs.

Some past research focuses on the adjustment to work that leads to learning and works well-being. Some people expect that the job transition will strengthen the challenging work aspect, such as learning standards, which will lead to better learning outcomes. For example, Bacon \& Blyton (2002) stated that the union reactions of the Military Commitment and the Moderate Opposition, instead, involve tactical negotiating dilemmas, since they may break away from the ideological tradition of the union branch. The Militant union, which participates in inclusive negotiations, has the possibility that employers may cooperate only in order to facilitate solidarity with the union. It could not be seen that the union is reverting to harsh tactics of distributional bargaining to ensure improvements in terms and benefits in 
exchange for the organisation of the labour reform (Boxall \& Haynes, 1997; Blyton et al., 1996).

For the meantime, Frost (2001) has demonstrated that local unions are reacting to nearly similar conditions in various areas in which management is initiating a workplace restructuring. The response was related to results that met all stakeholders ' needs: management, employees and the union. As for the Interventionist Response, the local union whose reactions in a Pragmatic way relies on managers to take decisions unique to their place of work and to agree with management on the consequences of those changes concerning the process of bargaining with them in the transition process. It is important to remember that in both Interventionist and Pragmatic reactions, the local union reacts to the management-based change in the workplace. Next, the Apathetic Response is distinguished by the lack of bargaining by the local union for reform in workplace management. In other cases, the syndicate sees the restructuring undertaken by management not as impacting its members ' interests and hence does not respond to these reforms.

There was an Obstructionist reaction which is distinguished by the union's refusal to consider modifying the position of work introduced by management. Few negotiations have been held, and the participants are forced to withdraw, all administrators being forced to abandon their initial proposal. This response is focused on the union's desire to maintain its workers' influence and assets, whether they be salaries, working hours or working hours. Since a local union has a more significant influence over its management counterpart, from the practical point of view of the union, it makes sense to do anything to serve its members' best interests. In this report, we have spoken about a wide variety of reactions by the labour union to the organisational transformation or reorganisation while also describing how employees will respond to job transfers. As we know, job transitions between employees will affect performance goals at work, which can influence success at work instantly. There are also hypotheses, that "job change" is not something that tends to have an inert impact and cannot naturally be changed in any employee and social activity in order to quantify the effect of a work environment on a person's psychological status. Consequently, it would provide a strong incentive for workers to strengthen themselves for a healthier future in the company. The objectives of this review were, therefore, to systematically evaluate and synthesise the existing literature in some factors of job changes, how the trade union response to the problem of job changes during uncertain times and outline future research agenda within the domains.

\section{Methods}

Design

This study conducted a systematic literature review by relevant criteria from the Preferred Reporting item for Systematic Reviews and Meta-Analysis (PRISMA). It consists of five subsections including search strategy, inclusion and exclusion criteria, eligibility, data abstraction and analysis.

Search Strategy

A systematic search strategy was implemented through two electronic databases, which are Google Scholar and ScienceDirect. The keywords in the titles and abstracts were used in the search process including "job change", "job re-engineering", "job redesign", "workplace restructuring", "workplace reorganisation", "job reshuffle" AND "trade union". 
The process yielded a result of 2298 documents from Google Scholar, and Science Direct databases were retrieved.

Inclusions and Exclusion Criteria

The first criterion for inclusion concerned a timeline, and a period of ten years, between the years of 2010 to 2020 was selected. The second inclusion criterion was document types, journal (research articles) with empirical data as primary sources were selected. The third inclusion was articles published in the social sciences field, as well as management and business and psychology field, were selected to increase the possibility of retrieving related articles. The fourth inclusion was regarding on region, where all countries were selected in this review. The fifth was focusing on articles published in the English language. The final inclusion was including the selection of a sample involving the trade union response. Meanwhile, the exclusion criteria were systematic review, meta-analysis, chapter in book, review papers, non-research papers, non-English and samples other than the trade union as stated in Table 1. In general, as stated in Figure 1, a total of 1584 articles were excluded based on these criteria, After the identification process, out of 2298 documents to be screened 584 documents were retained for the next stage.

Eligibility

A total of 574 articles were prepared for the third stage known as the eligibility. Eligibility is a process that includes or excludes manually according to the authors' specific criteria. At this point, the names, abstracts and key contents of all the papers were carefully reviewed in order to ensure that they meet the inclusion criteria and fit to be included in the present study in order to achieve the purpose of the current analysis. Before the eligibility process was carried out, the duplicated documents were removes first. A total of 3 articles were traced as similar articles were excluded in both databases for the next phase. Finally, a total of 574 remaining articles are ready to be analysed.

Table 1: Inclusion and Exclusion Criteria

\begin{tabular}{|l|l|l|}
\hline \multicolumn{1}{|c|}{ Criteria } & \multicolumn{1}{c|}{ Inclusion } & \multicolumn{1}{c|}{ Exclusion } \\
\hline Timeline & Between 2010 to 2020 & Below 2010 \\
\hline Document types & Journal (research articles) & $\begin{array}{l}\text { Systematic review, meta- } \\
\text { analysis, chapter in book, } \\
\text { review papers, non-research } \\
\text { papers. }\end{array}$ \\
\hline Subject Area & $\begin{array}{l}\text { Social Sciences, Business } \\
\text { and Management }\end{array}$ & $\begin{array}{l}\text { Other than Social Sciences, } \\
\text { Business and Management }\end{array}$ \\
\hline Countries and territories & All countries & Non-English \\
\hline Language & English & Non-trade union \\
\hline Sample & Trade union & \\
\hline
\end{tabular}

Data abstraction and analysis

The remaining articles were assessed, checked and examined following the eligibility process. The data were collected to define important themes and sub-themes for the present analysis by reviewing the titles, abstracts and the articles full, thoroughly. The following responses were sought during the review process: (a) the research design; (B) the response of trade union; (c) the way to solve job changes; (d) the sample selection and (e) study region. 574 papers have been found from the quest mentioned above. After reading the abstract, 564 papers were excluded because they were not applicable to study issues. Neither did these 
omitted articles test the association between the trade union and job changes and restructuring. Ten articles left after a comprehensive review of the full text. The description of each of the papers in this analysis was provided in Table 1 and Table 2.

\section{Findings}

The information of the selected articles about trade union response towards job changes factors during uncertain times and trade union ways to solve the problem of job changes. The author, year of publication, the title of journal articles, setting of the study, participants, and main findings of each literature are clearly outlined. Clearer and better view of the information related to the to trade union response towards job changes factors during uncertain times in Table 1 while trade union ways to react the problem of job changes in Table 2. 
INTERNATIONAL JOURNAL OF ACADEMIC RESEARCH IN BUSINESS AND SOCIAL SCIENCES Vol. 11, No. 2, 2021, E-ISSN: 2222-6990 @ 2021 HRMARS

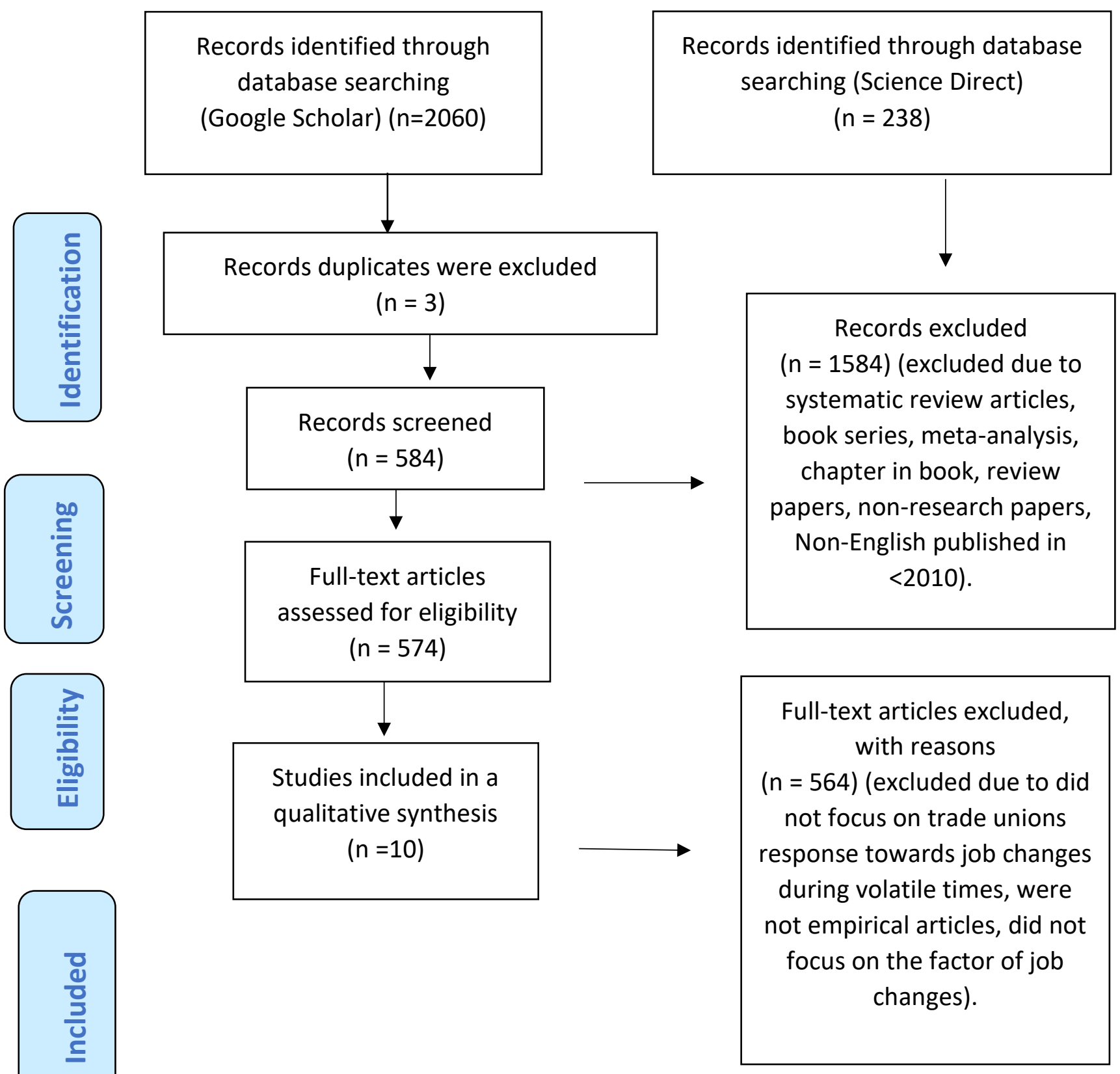

Figure 1. The flow diagram of the study.

(Adapted from Moher et al., 2009.) 
Table 1: Summary of related literature.

\begin{tabular}{|c|c|c|c|c|c|}
\hline $\begin{array}{l}\text { Author } \\
\text { (Year) / } \\
\text { Journal }\end{array}$ & Title of Article & $\begin{array}{l}\text { Main Study } \\
\text { Design }\end{array}$ & Country & Participants & Main findings \\
\hline $\begin{array}{l}\text { Kaikobad, } \\
\text { N. K., \& } \\
\text { Bhuiyan, M. } \\
\text { Z. A. (2012) } \\
\text { / IOSR } \\
\text { Journal of } \\
\text { Business } \\
\text { and } \\
\text { Manageme } \\
\text { nt }\end{array}$ & $\begin{array}{l}\text { Job Switching of } \\
\text { Garment } \\
\text { Workers } \\
\text { Decreasing } \\
\text { Productivity: An } \\
\text { Analytical } \\
\text { Research }\end{array}$ & Quantitative & Bangladesh & $\begin{array}{l}\text { factories } \\
\text { workers }\end{array}$ & $\begin{array}{l}\text { Workers change } \\
\text { their positions } \\
\text { for a decent } \\
\text { wage, } \\
\text { transportation, } \\
\text { decent } \\
\text { environments, } \\
\text { and avoid } \\
\text { workplace } \\
\text { violence. }\end{array}$ \\
\hline $\begin{array}{c}\text { Halteh, J., } \\
\text { Arrowsmith } \\
\text {, J., Parker, } \\
\text { J., Zorn, T. } \\
\text { E., \& } \\
\text { Bentley, T. } \\
\text { (2018) / } \\
\text { Labour \& } \\
\text { Industry: A } \\
\text { Journal of } \\
\text { The Social } \\
\text { And } \\
\text { Economic } \\
\text { Relations } \\
\text { Of Work }\end{array}$ & $\begin{array}{l}\text { The impact of } \\
\text { technology on } \\
\text { employment: a } \\
\text { research } \\
\text { agenda for New } \\
\text { Zealand and } \\
\text { beyond }\end{array}$ & $\begin{array}{l}\text { Mixed- } \\
\text { method }\end{array}$ & $\begin{array}{c}\text { New } \\
\text { Zealand }\end{array}$ & Employees & $\begin{array}{l}\text { Essential to help } \\
\text { understand the } \\
\text { drivers, } \\
\text { limitations, scale } \\
\text { and impacts of } \\
\text { technological } \\
\text { transition on } \\
\text { employee } \\
\text { productivity and } \\
\text { success, as well } \\
\text { as financial } \\
\text { results. }\end{array}$ \\
\hline $\begin{array}{c}\text { Bachmann, } \\
\text { R., Bechara, } \\
\text { P., \& } \\
\text { Vonnahme, } \\
\text { C. (2020) / } \\
\text { De } \\
\text { Economist }\end{array}$ & $\begin{array}{l}\text { Occupational } \\
\text { Mobility } \\
\text { in Europe: } \\
\text { Extent, } \\
\text { Determinants } \\
\text { and Consequen } \\
\text { ces }\end{array}$ & Quantitative & $\begin{array}{c}26 \\
\text { European } \\
\text { Countries }\end{array}$ & Countries & $\begin{array}{l}\text { Their features } \\
\text { strongly } \\
\text { determine } \\
\text { occupational } \\
\text { adjustments. } \\
\text { Occupational } \\
\text { changes have } \\
\text { had an impact } \\
\text { on the structure } \\
\text { of the economy. }\end{array}$ \\
\hline $\begin{array}{c}\text { Bacon, N., } \\
\text { Blyton, P., } \\
\& \\
\text { Dastmalchi } \\
\text { an, A. } \\
(2010) / \\
\text { Human } \\
\text { Relations }\end{array}$ & $\begin{array}{l}\text { The impact of } \\
\text { organisational } \\
\text { change on } \\
\text { steelworkers in } \\
\text { craft and } \\
\text { production } \\
\text { occupational } \\
\text { groups }\end{array}$ & Quantitative & $\begin{array}{l}\text { United } \\
\text { Kingdom }\end{array}$ & $\begin{array}{l}\text { Workers, union } \\
\text { representatives } \\
\text { and managerial } \\
\text { level employees }\end{array}$ & $\begin{array}{l}\text { Increased } \\
\text { stability, } \\
\text { earnings and } \\
\text { morals) } \\
\text { Increased threat } \\
\text { of } \\
\text { subcontracting }\end{array}$ \\
\hline
\end{tabular}




\begin{tabular}{|c|l|l|l|l|l|}
\hline & & & & $\begin{array}{l}\text { and job } \\
\text { restructuring }\end{array}$ \\
\hline $\begin{array}{c}\text { Latzke, M., } \\
\text { Kattenbach, } \\
\text { R., } \\
\text { Schneidhof } \\
\text { er, T., } \\
\text { of voluntary job } \\
\text { changes in } \\
\text { Germany: A } \\
\text { Fultilevel } \\
\text { analysis for } \\
\text { Mayrhofer, } \\
\text { W. (2016), } \\
\text { Journal of } \\
\text { Vocational } \\
\text { Behavior }\end{array}$ & Quantitative & Germany & $\begin{array}{c}\text { Employer, } \\
\text { employees, } \\
\text { trade union }\end{array}$ & $\begin{array}{l}\text { Drastic job } \\
\text { changes due to } \\
\text { shifting job, } \\
\text { social and } \\
\text { corporate } \\
\text { conditions } \\
\text { appears to be } \\
\text { misleading. }\end{array}$ \\
\hline
\end{tabular}

Table 2: The ways how the trade union react to the problems of job changes

\begin{tabular}{|c|c|c|c|c|c|}
\hline $\begin{array}{l}\text { Author } \\
\text { (Year) / } \\
\text { Journal }\end{array}$ & Title of Article & $\begin{array}{l}\text { Main Study } \\
\text { Design }\end{array}$ & Country & Participants & Main findings \\
\hline $\begin{array}{c}\text { Sørensen, O. } \\
\text { H., \& } \\
\text { Holman, D. } \\
\text { (2014) / } \\
\text { Work \& } \\
\text { Stress: An } \\
\text { International } \\
\text { Journal of } \\
\text { Work, Health } \\
\text { \& } \\
\text { Organisation } \\
\text { s }\end{array}$ & $\begin{array}{l}\text { A participative } \\
\text { intervention to } \\
\text { improve } \\
\text { employee well- } \\
\text { being in } \\
\text { knowledge work } \\
\text { jobs: A mixed- } \\
\text { methods } \\
\text { evaluation study }\end{array}$ & $\begin{array}{l}\text { Mixed } \\
\text { method }\end{array}$ & Denmark & $\begin{array}{l}\text { Engineering } \\
\text { companies' } \\
\text { workers }\end{array}$ & $\begin{array}{l}\text { Measures to } \\
\text { enhance } \\
\text { supervision and } \\
\text { input from peers } \\
\text { and formalise } \\
\text { guidelines and } \\
\text { processes for job } \\
\text { planning and } \\
\text { social } \\
\text { engagement may } \\
\text { have beneficial } \\
\text { impacts on the } \\
\text { features of } \\
\text { knowledge-based } \\
\text { practice and well- } \\
\text { being. }\end{array}$ \\
\hline $\begin{array}{c}\text { López- } \\
\text { Andreu, M. } \\
\text { (2019) / } \\
\text { European } \\
\text { Journal of }\end{array}$ & $\begin{array}{l}\text { Neoliberal } \\
\text { trends in } \\
\text { collective } \\
\text { bargaining and } \\
\text { employment } \\
\text { regulation in }\end{array}$ & $\begin{array}{c}\text { Mix- } \\
\text { method }\end{array}$ & $\begin{array}{c}\text { Spain, } \\
\text { Italy, UK }\end{array}$ & Employees & $\begin{array}{l}\text { Managed } \\
\text { decentralisation } \\
\text { allows unions to } \\
\text { hold an exact } \\
\text { legislative } \\
\text { position, and }\end{array}$ \\
\hline
\end{tabular}




\begin{tabular}{|c|c|c|c|c|c|}
\hline $\begin{array}{l}\text { Industrial } \\
\text { Relations }\end{array}$ & $\begin{array}{l}\text { Spain, Italy, and } \\
\text { the UK: From } \\
\text { institutional } \\
\text { forms to } \\
\text { institutional } \\
\text { outcomes }\end{array}$ & & & & $\begin{array}{l}\text { firm-level } \\
\text { bargaining is } \\
\text { governed } \\
\text { through multi- } \\
\text { employer } \\
\text { agreements; in } \\
\text { countries with } \\
\text { disorganised } \\
\text { decentralisation, } \\
\text { multi-employer } \\
\text { agreements do } \\
\text { not have a lower- } \\
\text { level structure. }\end{array}$ \\
\hline $\begin{array}{c}\text { Säve- } \\
\text { Söderbergh, } \\
\text { J. (2019) / } \\
\text { Journal of } \\
\text { Economic } \\
\text { Behavior and } \\
\text { Organization }\end{array}$ & $\begin{array}{l}\text { Gender gaps in } \\
\text { salary } \\
\text { negotiations: } \\
\text { Salary requests } \\
\text { and starting } \\
\text { salaries in the } \\
\text { field }\end{array}$ & $\begin{array}{c}\text { Quantitativ } \\
\text { e }\end{array}$ & Sweden & $\begin{array}{l}\text { Employer, } \\
\text { employees and } \\
\text { trade unions } \\
\text { members. }\end{array}$ & $\begin{array}{l}\text { Better wage } \\
\text { negotiation } \\
\text { outcomes: to } \\
\text { obtain more, less } \\
\text { or more } \\
\text { conditionally on } \\
\text { the offer. }\end{array}$ \\
\hline $\begin{array}{c}\text { Dawson, C., } \\
\text { Veliziotis, M., } \\
\text { Pacheco, G., } \\
\text { \& Webber, D. } \\
\text { (2015)/ } \\
\text { Social } \\
\text { Sciences \& } \\
\text { Medicine }\end{array}$ & $\begin{array}{l}\text { Is temporary } \\
\text { employment a } \\
\text { cause or } \\
\text { consequence of } \\
\text { poor mental } \\
\text { health? A panel } \\
\text { data analysis. }\end{array}$ & $\begin{array}{c}\text { Quantitativ } \\
\mathrm{e}\end{array}$ & $\begin{array}{l}\text { United } \\
\text { Kingdom }\end{array}$ & $\begin{array}{l}\text { Households } \\
\text { (> 5000)and } \\
\text { individuals } \\
(>10,000)\end{array}$ & $\begin{array}{l}\text { Permanent } \\
\text { workers who } \\
\text { would be in } \\
\text { temporary jobs in } \\
\text { the future } \\
\text { experience lower } \\
\text { levels of mental } \\
\text { well-being } \\
\text { compared to } \\
\text { people who are } \\
\text { never in } \\
\text { temporary } \\
\text { employment. }\end{array}$ \\
\hline $\begin{array}{c}\text { Lee, J. W. } \\
\text { (2013) / } \\
\text { World } \\
\text { Development }\end{array}$ & $\begin{array}{l}\text { The In-House } \\
\text { Contracting } \\
\text { Paradox: } \\
\text { Flexibility, } \\
\text { Control, and } \\
\text { Tension }\end{array}$ & Qualitative & $\begin{array}{l}\text { South } \\
\text { Korea }\end{array}$ & $\begin{array}{c}\text { Regular \& } \\
\text { Contract } \\
\text { workers, } \\
\text { Contractors \& } \\
\text { Managerial } \\
\text { staff, }\end{array}$ & $\begin{array}{l}\text { The involvement } \\
\text { of foreign } \\
\text { workers in the } \\
\text { factory } \\
\text { production areas } \\
\text { is fraught with } \\
\text { the friction that } \\
\text { results from the } \\
\text { indispensable } \\
\text { coordination } \\
\text { involving regular } \\
\text { and contract } \\
\text { workers, as well } \\
\text { as other }\end{array}$ \\
\hline
\end{tabular}




\begin{tabular}{|l|l|l|l|l|l|}
\hline & & & & workplace actors \\
\hline
\end{tabular}

\section{Discussion}

Kaikobad \& Bhuiyan (2012) found that most male workers left their employment for a higher wage. Of the 20 migrant workers, four changed their jobs in order to get better pay. It was seen as a common situation for male workers who are adjusting their job to earn better wages. In the meantime, the majority of female workers are shifting their positions in travel, respectable environments or crime. In the sample as a whole, it is observed that the highest rate of change of jobs with decent pay for male employees, both within and outside Dhaka City, whereas the highest rate for female workers is adjusted to a good atmosphere and free from violence. Garments are the nation's largest job place for international earnings. As far as development is concerned, moving jobs regularly by textile staff is very much hindering the willingness of consumers to fulfil demand on time.

Halteh et al. ( 2018) investigated workforce technology, which has an impact on skills, jobs and training. The complexity of the market, and the rise of social sites are driving digital innovations to overwhelm the relevant young generation of technical employees - secondly, the impact on work habits. Employment flexibility has shifted sectors, international competition, the reform of labour law, and the decline of labour unions are all influenced by new technologies. It runs the risk of hollowing out current commitments on salaries and conditions of work. Thirdly, it affects the supervision and control of workers. Innovations provide employers with a seductive array of techniques that better track and strengthen employment. Technological developments have potentially significant consequences for quality and the number of work leading to shifts in qualifications needs and workforce trends across nearly all sectors and occupations. In line with other nations, New Zealand employers, labour unions and decision-makers put great emphasis on understanding the consequences of technology for jobs. Changes in technology and its implementation will quickly lead to science that is itself increasingly redundant or obsolete.

Bachmann et al. (2020) focusing first on the magnitude and personal determinants, the findings reveal that workplace mobility is a prevalent feature in European labour markets. Occupational changes are positively affected by their human traits. In general, household features do not play an essential role in this respect, except marriage, which goes hand in hand with lower occupational mobility. Labour diversity analysis relies on the idea of work transition. From the point of view of the worker, versatility in the workplace will contribute to the development of particular abilities and job-specific requirements. Generally, this better equilibrium is mirrored in higher incomes. This fact could also contribute to a negative opinion on the part of the staff of elevated labour market uncertainty attributable to high career mobility. At the level of the worker, the relationship to pay versatility is a necessary consequence of occupational mobility.

According to Latzke et al. ( 2016), studying the individual impact of voluntary work changes in Germany Revealed a fall in wage growth and little rise in work satisfaction. His leads to the reduced importance of the general findings on contemporary labour studies to the German labour market. However, wage rises for stayers have declined similarly. As a result, the fiscal surplus of changers opposed to stayers appears steady on average and even 
paying off moving jobs, although just in nominal terms. In general, wages tends to be more competitive in Germany than in other countries with a collective bargaining structure. Thus, for Germany - considering limited visibility in collective negotiations and fewer works councils over time - there is still more boundary, and less inequality overtime was owing to distinct improvements in wages than in other nations such as the United Kingdom or the United States. This fact precedes to particular applicability to the German labour market of general assumptions on contemporary work changes research.

Bacon et al. ( 2010) outlined the constraints imposed by the horizontal division of occupational labour on the coordination initiative. In this process, technically based labour unions sought pay and voluntary severance schemes that secured the rights of their workers and shared certain concessions amongst various occupational classes. The overall pessimistic attitudes towards job reshuffling reflect the problems seen in other studies. in creating employee enthusiasm for reform when workplaces are under pressure. Labour-based labour unions sought pay and voluntary severance schemes that secured the rights of their workers and shared certain concessions amongst various job classes.

Sorensen \& Holman (2014) has broadened our understanding of how organisationallevel occupational health interventions will assist the workers and provide further light on the conditions that influence the effectiveness of those knowledge initiatives. Also, this research indicated that programs for information employees in the field of workplace health should concentrate on reducing job complexities and uncertainties, and on improving staff's capacity to manage tasks with others. The results indicate that efforts to enhance the management and input of peer representatives and formalise rules and procedures governing career preparation and social engagement may have a positive influence on the characteristics of employment and well-being dependent on expertise. Adopting techniques commonly used in workplace health initiatives such as greater discretion and variation in jobs can be carried out, to recognise that the complexity and ambiguity of the role will be increased. They demonstrated that an electronic logbook was used to document time intervals for researchers to respond to, for example, group members' feedback into the programme, engaging in the application process. Employees have developed and introduced an initiative for management reviews using a table-based approach to control of each employee's recommendations weekly. Union workers have built a peer support mechanism to improve and organise work procedures and reinforce team relations, providing feedback that staff could use to hold a feedback session.

According to the Lopez-Andreu study (2018), centralised decentralisation allows trade unions to retain a stable legislative position. The firm-level contracts are governed through multi-employer agreements in countries with disorganised decentralisation, and multiemployer agreements do not have a lower-level base. It acknowledges a general move towards liberalisation but insists that the term covers somewhat different realities and that 'grey rather than illuminated' has demonstrated that, in all three countries, the liberalisation policies adopted during austerity interacted with the existing institutional models and the effects of the 2008 recession. The British model has seen fewer reforms than in the other two nations, and the steps adopted have applied the current flexible private sector structures to the public sector. Ses diverse perspectives indicate that the stresses of liberalisation are being built through the current variety of institutional structures. 
Dawson et al. ( 2015 ) found that labour market status and mental health are related, and current evidence shows that lower labour market status is associated with worse mental health. It is therefore debatable that the eventual transition from permanent to temporary jobs is associated with poor mental health. Then, Säve-Söderbergh (2019) claimed that, after both the bargaining action and resulting result for the same person, this research illustrates, in particular, the importance of identifying gender differences in negotiating behaviour. The gender difference in starting salaries is mostly reduced when females have lower wage requirements, especially among those with higher starting salaries. Even though the sample examined was homogeneous in many ways, it is interesting that the gender difference, although narrow in size, remained similar to the distribution as a whole, indicating that variables outside the reach of the analysis were considered. Hence, negotiating behaviour contribute to gender disparities in starting wages, especially in terms of gender norms. Finally, Lee ( 2013) suggested that management has preferred to strengthen the governance structure of its power. By the mid-2000s, standardising contractors' processes and working practices was the most effective approach to meet this target. Increased utilisation of temporary workers has led to more substantial union participation, as another consequence is that more labour management agreements are required. The decisive involvement of the management of the user company and the labour union in the operational activities of the contractor companies has been found to have had a considerable effect on the well-being of the contract workers, which, however, poses ethical concerns about the real position of the user company as an employer and the secret workplace ties of non-standard employees. As a result, the workforce ratio of all contracting firms has been consolidated to a similar amount, and workers have been redeployed in such a manner that each company is mainly engaged in a single manufacturing facility.

\section{Limitations \& Recommendation for Future Research}

The difference between the studies studied in terms of sample characteristics, tools, tools for data collection and organisational descriptions of research variables may have led to difficulties in trying to generalise the results. There is also no further discussion of the common practice prejudice for cross-section design for this review study, in particular the use of limited academic databases. The future research agenda, in the first place, centres on a systematic analysis of the theoretical context for the trade union response during volatile periods. Second, further analysis will be conducted on decisions to alter the content of the work changes that is included within the framework of a horizontal division of labour which restricts the degree to which the work is initially transformed. Third, more empirical studies are required on technology advances, and innovation has potentially significant consequences for quality as well as for the number of workers due to shifts in work skills needs, new technology advancements and workforce trends across nearly all markets, occupations and periods. Little is understood, however, about the contingencies and processes associated with technological changes that form its application and influence on job changes and union reactions, particularly during periods of health crises such as the current COVID-19 pandemic. Hence, there is an ability, empirical realities and exigency to revisit the workers' union response in the course of the COVID-19 crisis and further redirect the attention and strategic lens to extensive digital innovation, new work skill, the importance of job changes and structural disparities. 


\section{Conclusions}

Based on findings and discussions, the studies highlighted in this review examined two objectives, namely to investigate trade union response towards job changes among employees during uncertain times and to examine the way how the trade union solve the problem of job changes. Firstly, most of the studies stated that most of the make workers are changing their jobs for a good salary and also there is a common scenario for male workers who were shifting their jobs to earn better wages. From this result of the discussion, we can conclude that there are the factors that contributed to job changes among employees which are transportation, sound environments, harassments and more. Thus, there also provide the information analysis which is the ways how the trade union solve the problem of job changes which are including organised decentralisation that enable unions to maintain a decisive regulatory role, and firm-level negotiation. This process is regulated by multi-employer agreements in countries with disorganised decentralisation. Therefore, for the future study needs to describe how trade union really towards job changes among employees and deciding to solve the problem of job changes during volatile times.

Besides that, prior research has often viewed that job changes represent much positive impact on employees, such as improving employee well-being in knowledge work jobs. The approach of this topic has taken in collective bargaining by a union appeared to be at least as necessary as mobilising union members who are in securing gains for employees. This study also demonstrates that job changes are an impact that very nature of the work and the context which provides job performance among employees that may explain how these job changes influence employee functioning at work during uncertain periods. This finding is significant to generate more knowledge of the processes that developed from job changes or rearrangement from employers. Thus, there are factors and ways which needs to be explained in this study in more detail given by the trade union. Moreover, this study is about union response related to job changes that could increase employee learning about innovation and new skill in a new place, and organisation are advised to support employees by providing an opportunity for competence development in a new situation.

\section{Acknowledgement}

The authors thank Universiti Malaysia Sabah (UMS) for valuable help in the research and publication process. This research was conducted within the larger project funding of UMS internal research grant SDN0077-2019.

\section{Corresponding Author}

Name: Azizan H Morshidi

Affiliation: Faculty of Social Sciences \& Humanities, Universiti Malaysia Sabah.

Address: Universiti Malaysia Sabah, JIn UMS, 88400 Kota Kinabalu, Sabah, Malaysia.

Email: azizanm@ums.edu.my 


\section{References}

Bachmann, R., Bechara, P., \& Vonnahme, C. (2020). Occupational mobility in Europe: Extent, determinants and consequences. De Economist, 168(1), 79-108.

Bacon, N., \& Blyton, P. (2002). Militant and moderate trade union orientations: what are the effects on workplace trade unionism, union-management relations and employee gains?. International Journal of Human Resource Management, 13(2), 302-319.

Bacon, N., Blyton, P., \& Dastmalchian, A. (2010). The impact of organisational change on steelworkers in craft and production occupational groups. Human Relations, 63(8), 1223-1248.

Boxall, P., \& Haynes, P. (1997). Strategy and trade union effectiveness in a neo-liberal environment. British Journal of Industrial Relations, 35(4), 567-591.

Blyton, P., Bacon, N., \& Morris, J. (1996). Working in steel: Steelworkers' attitudes to change 40 years on. Industrial Relations Journal, 27(2), 155-165.

Dawson, C., Veliziotis, M., Pacheco, G., \& Webber, D. J. (2015). Is temporary employment a cause or consequence of poor mental health? A panel data analysis. Social Science \& Medicine, 134, 50-58.

Halteh, J., Arrowsmith, J., Parker, J., Zorn, T. E., \& Bentley, T. (2018). The impact of technology on employment: a research agenda for New Zealand and beyond. Labour \& Industry: A Journal Of The Social and Economic Relations of Work, 28(3), 203-216.

Kaikobad, N. K., \& Bhuiyan, M. Z. A. (2012). Job switching of garment workers decreasing productivity: An analytical research. IOSR Journal of Business and Management, 4(4), 1-7.

Kelly, J. (2012). Rethinking industrial relations: Mobilisation, collectivism and long waves. Routledge.

Lee, J. W. (2013). The in-house contracting paradox: Flexibility, control, and tension. World Development, 45, 161-174.

López-Andreu, M. (2019). Neoliberal trends in collective bargaining and employment regulation in Spain, Italy and the UK: From institutional forms to institutional outcomes. European Journal of Industrial Relations, 25(4), 309-325.

Latzke, M., Kattenbach, R., Schneidhofer, T., Schramm, F., \& Mayrhofer, W. (2016). Consequences of voluntary job changes in Germany: A multilevel analysis for 19852013. Journal of Vocational Behavior, 93, 139-149.

Moher, D., Liberati, A., Tetzlaff, J., Altman, D. G., \& Prisma Group. (2009). Preferred Reporting Items For Systematic Reviews And Meta-Analyses: the PRISMA statement. PLoS Med, 6(7), e1000097.

Säve-Söderbergh, J. (2019). Gender gaps in salary negotiations: Salary requests and starting salaries in the field. Journal of Economic Behavior \& Organization, 161, 35-51.

Sørensen, O. H., \& Holman, D. (2014). A participative intervention to improve employee well-being in knowledge work jobs: A mixed-methods evaluation study. Work \& Stress, 28(1), 67-86.

Villajos, A., García-Ael, C., \& Topa, G. (2019). Job crafting among labor union representatives: Its impact on work engagement and job satisfaction. Social Sciences, 8(1), 20. 